\title{
Three steps forward, one step back? Reflections on "google taxes" and the destination-based corporate tax
}

DOI 10.1515/ntaxj-2016-0007

Received Jul 04, 2016; accepted Sep 16, 2016

\section{Introduction: Why is the Corporate Tax Robust?}

A large puzzle underlies the recent G20 and OECD Base Erosion and Profit Shifting (BEPS) project. If the scope of BEPS is as broad as the reports suggest, why are corporate tax revenues in the OECD so robust?

The final OECD report on BEPS action 11 suggest that BEPS activities result in between $\$ 100$ and $\$ 240$ billion in annual lost revenue from corporate income taxes (CIT) on a global basis. The wide spread between these two numbers indicates the significant uncertainty involved. But even the higher number represents a relatively small portion of total global CIT revenues, since it is only about half of the annual CIT revenue of the US alone. Moreover, overall OECD revenue data do not indicate that BEPS has had a significant impact on CIT revenue, since those have held steady at $8-10 \%$ of total revenue since the 1980 s (i.e., before BEPS became a significant issue). ${ }^{1}$

These data are surprising in light of what we know about the extent of tax avoidance by U.S. multinationals. Currently, U.S.-based multinationals have accumulated over \$2.5 trillion in low tax jurisdictions offshore, and the U.S. tax on that income (most of which has been accumulated since 2005, when a one year amnesty allowed previous profits to be repatriated) is about $\$ 800$ billion, which is also the ten year estimate of the cost of deferral to the U.S. Treasury. ${ }^{2}$ These data suggest that if the OECD esti-

Reuven S. Avi-Yonah: Irwin I. Cohn Professor of Law, the University of Michigan; Professor in Residence, IBFD

1 https://data.oecd.org/tax/tax-on-corporate-profits.htm\# indicator-chart.

2 https://www.treasury.gov/resource-center/tax-policy/Documents/ Tax-Expenditures-FY2016.pdf. mate is right, a very high percentage of total BEPS activity is due to U.S. multinationals.

This estimate suggests that US tax policy is important to the rest of the world, including Europe and the Nordic region. The US is the largest economy in the world. If the US were to tax its multinationals more effectively, this would make it much easier for smaller economies to do the same without worrying about competition from low-taxed US multinationals.

How do other countries avoid large scale BEPS activities by their own multinationals? One explanation is that most of them have more robust CFC rules than the U.S. Since the enactment of check the box (1997) and the CFC to CFC payments rule (2006), the U.S. CFC rules (Subpart F) have essentially become toothless, except in preventing repatriations. ${ }^{3}$ Other OECD countries tend to have more robust $\mathrm{CFC}$ rules which explicitly impose taxes on income accumulated in low tax jurisdictions and having no real connection to that jurisdiction. If the U.S. had CFC rules like Germany, France or Japan, the extent of low taxed income of U.S. multinationals would have been significantly reduced. ${ }^{4}$

Another explanation for the relative robustness of the CIT base to BEPS is the gradual downward ratcheting of the permanent establishment (PE) threshold. The PE threshold is entrenched in all the tax treaties and prevents source jurisdictions from taxing business profits of non-resident enterprises unless they have a PE in the source jurisdiction, which in turn requires some kind of physical presence directly or through an agent. This rule is clearly obsolete in the $21^{\text {st }}$ century, but it is hard to change given its

3 Avi-Yonah and Sartori, International Taxation and Competitiveness: Foreword, 65 Tax L Rev 313 (2012).

4 See Peter Koerver Schmidt, Taxation of Controlled Foreign Companies in Context of the OECD/G20 Project on Base Erosion and Profit Shifting as well as the EU Proposal for the Anti-Tax Avoidance Directive - An Interim Nordic Assessment, Nordic Tax J. (2016); for an empirical assessment of the effect of CFC rules see Avi-Yonah and Lahav, The Effective Tax Rates of the Largest US and EU Multinationals, 65 Tax L Rev 375 (2012). 
importance in the treaties. But over the past decade there has been a trend to gradually reduce the threshold, for example, by treating subsidiaries as the agents of their parent corporations and thus treating the parent as having a $\mathrm{PE}$ through its subsidiary. In addition, the invention of the "service PE" makes it easier to subject service providers to tax without much physical presence. ${ }^{5}$ A 2012 decision by the Spanish Economic Administrative Court went even further and held that an Irish company making sales through a web site that was hosted outside Spain, but that focused on the Spanish market, had a "virtual PE" in Spain. ${ }^{6}$

Since the market is less subject to tax competition pressures than the location of headquarters or production facilities, reducing the PE threshold makes it easier to prevent BEPS. This has recently led some jurisdictions to enact new taxes aimed specifically at structures that seek to exploit the domestic market while avoiding a PE. This article will discuss these taxes in the UK, Australia and India, explore their relationship to the BEPS project, and then consider whether further steps can be taken toward a destination-based corporate tax (DBCT) that will be a permanent cure for BEPS.

\section{The Three "Google Taxes"}

\subsection{The UK "Diverted Profits Tax"}

Even before BEPS was concluded, the UK enacted the "diverted profits tax" (DPT) that became effective on April 1, 2015. ${ }^{7}$ The DPT is intended primarily to address structures like Google's Double Irish Dutch Sandwich, which is contained in the guidance published by HMRC as Example 3. ${ }^{8}$

Under Example 3, the US parent of a multinational group (company A) owns a subsidiary incorporated in Ireland that is treated under Irish law as resident in a tax haven (company D) which owns the IP for the rest of the world. Company D licenses the IP to Company $\mathrm{C}$ in the Netherlands, which in turn licenses it to Company B in Ireland. Company B owns Company E which provides sales and service support in the UK, with all sales contracts being finalized by Company B in Ireland.

Under this structure, UK tax is only applied to the cost plus profits of company E, which are minimal. Companies

5 http://kluwertaxblog.com/2015/08/12/un-model-servicespermanent-establishment-what-you-do-not-where-you-do-it/. 6 Ruling of 15 March 2012, RG 2017-07.

7 FA 2015, sections 80, 81, 86.

8 HMRC, Diverted Profits Tax: Interim Guidance (March 2015), 37.

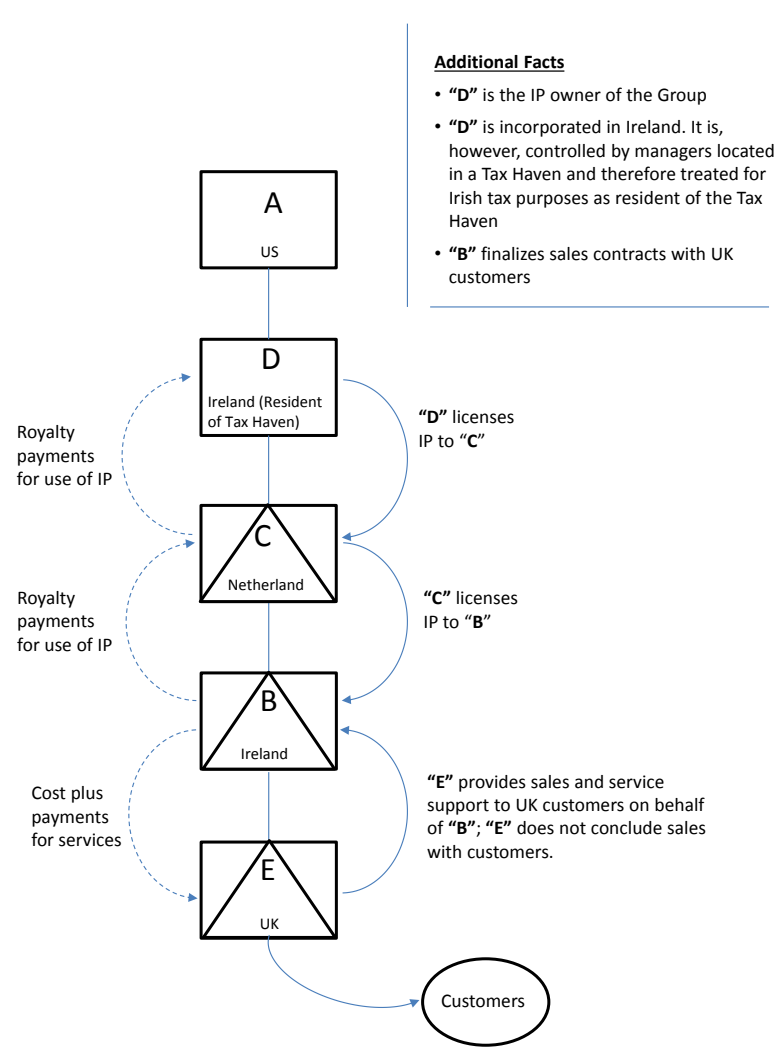

$\mathrm{B}, \mathrm{C}$ and $\mathrm{D}$ do not have a PE in the UK and are not subject to tax. Company B is taxable in Ireland, but most of its profits are payable as a royalty to Company $\mathrm{C}$, which it turn pays most of its profits to Company $\mathrm{D}$ in the tax haven. There is no withholding tax on the payment from Company $\mathrm{B}$ to $\mathrm{C}$ (because of the Ireland-Netherlands tax treaty) or from $\mathrm{C}$ to $D$ (because the Netherlands does not tax outbound royalties). The U.S. CFC rules do not apply because other than Company D, all the other entities in the group are disregarded under check the box, and their activities attributed to Company D (regarded under the US rules as resident in Ireland).

The DPT subjects this arrangement to UK tax because Company B's affairs are arranged so as to avoid a UK PE. The section 86 charge will apply where there is a non-UK resident company (Company $\mathrm{B}$ ) that is carrying on a trade; a UK resident (Company E, the "avoided PE") that is carrying on activities in the UK in connection with the supply of goods or services by Company B; it is reasonable to assume that the activity of Company E or Company B was designed to avoid Company B being subject to UK CIT; there is a "tax mismatch" in that the tax paid by Company B in Ireland is less than $80 \%$ of the tax avoided by Company 
$\mathrm{E}$; and tax reduction was one of the main purposes of the arrangement. ${ }^{9}$

If these conditions are satisfied, a 25\% DPT applies to the diverted profits (i.e., the profits that would have been taxable to Company B in the UK had it had a PE), measured initially as $30 \%$ of the deductions taken by Company B, with later adjustments (and credits for any foreign tax).

The DPT has been criticized as over-broad and as contrary to EU freedom of establishment rules. ${ }^{10}$ However, other writers have defended the DPT's compatibility with EU rules, and this issue will presumably be litigated if the UK remains in the EU. ${ }^{11}$

The DPT has also been criticized as in substance contradicting the UK tax treaties, which require an actual PE. HMRC has defended it as a new tax that is not subject to the treaties, and this issue is unlikely to arise because UK treaties are not "self executing" and have not been applied to the DPT by legislation. This means that a UK taxpayer cannot challenge the DPT as inconsistent with a UK tax treaty.

\subsection{The Australian Anti-Avoidance Tax}

In May 2015, the Australian government released the Tax Integrity Multinational Anti-Tax Avoidance Law (MAAL), which was designed to "prevent foreign corporations from using complex, contrived and artificial schemes that enable them to have substantial sales activities in Australia, but pay little or no tax anywhere."12 Unlike the DPT, this is not a new tax, but an amendment to Australia's GAAR (part IVA of the Income Tax Assessment Act 1936). The MAAL became effective on January 1, 2016 for enterprises with annual income over AUD 1 billion.

9 FA 2015 S. 86.

10 Dan Neidle, The Diverted Profits Tax: Flawed by Design? 2015 British Tax Review 147 (2015).; Heather Self, The UK's New Diverted Profit Tax: Compliance with EU Law, 43 Intertax 333 (2015); Jonathan Peacock, U.K.'s Diverted Profits Tax: A Regime Much, Much Broader Than its True Target? 17 European Tax Service 4 (2015).

11 Sol Picciotto, The U.K.'s Diverted Profits Tax: An Admission of Defeat or a Pre-Emptive Strike?, Tax Notes International 239 (January 19, 2015); Paul Rutherford, The U.K.'s Google Tax- First Thoughts, 42 Tax Planning International Review 4 (2015); Luca Cerioni, The New "Google Tax": The "Beginning of the End" for Tax Residence as a Connecting Factor for Tax Jurisdiction? European Taxation 185 (May, 2015); Philip Baker, Diverted Profits Tax: A Partial Response, 2015 British Tax Review 167 (2015) (the writer advised HMRC on the compatibility of the DPT with EU law and tax treaties).

12 AU, Exposure Draft Explanatory Material, Para. 1.10.
New ITAA Section 177DA applies if a non-resident of Australia sells good or services to an unrelated Australian resident, income from such sales is not attributable a a PE, and activities are undertaken by an Australian associate of the provider in connection with the sale. Under these circumstances, if it is reasonable to conclude that the scheme is designed to avoid income attributable to a PE and tax reduction was a principal purpose, the ATO is free to disregard the arrangement. ${ }^{13}$

This rule was likewise designed to address structures like the "Double Irish Dutch Sandwich". The Explanatory Materials contain an example of B Company that provides supplies in Australia and owns SubCo in Australia to provide support, but all contracts are entered into with B Co. B Co. Pays a large royalty to C Co., located in a non-tax jurisdiction, with no withholding tax. Under those circumstances, B Co would be treated as having a PE in Australia and the royalty from B to $C$ Co. Treated as an expense incurred by the PE and subject to withholding tax. ${ }^{14}$

The MAAL has been defended as consistent with Australia's tax treaties because it is an anti-avoidance rule, and the PE limit should not apply when the business profits are not taxed by the country of residence. ${ }^{15}$ In addition, in Australia treaty overrides are possible, so a treaty based challenge to the MAAL is unlikely. ${ }^{16}$

\subsection{The Indian Equalization Tax}

In February 2016, Indian Finance Minister Shri Arun Jaitley proposed as part of Finance Bill 2016 an "equalization levy" on certain digital transactions into India. This proposal followed a loss by the Indian revenue authorities in the Right Florists case, where the Income Tax Appellate Tribunal rules that payments by residents to Google and Yahoo for advertising services aimed at the Indian market could not be taxed because they were business profits and the providers did not have a PE in India.

The Equalization Levy is a 6\% withholding tax applied to the gross consideration paid by Indian service recipients engaged in a business to a non-resident that does not have

13 Draft EM, para. 1-40.

14 Draft EM, Examples 1.14, 1.15.

15 Michael Butler And Marianna Danby, Draft Legislation Released for Anti-Google Tax, Int'l Transfer Pricing Journal 349 (Nov. 2015); Douglas Fone, 16 Transfer Pricing Int'l J. 24 (2015); David Richardson, Corporate Tax Avoidance, the Australia Instituite, Submission 62 (Feb. 2015).

16 https://www.ibfd.org/IBFD-Products/Journal-Articles/Bulletinfor-International-Taxation/collections/bit/pdf/bifd060504.pdf. 
a PE in India for online advertisement and related services, if the total amount exceeds INR 100,000.

The Equalization levy has been criticized as inconsistent with India's tax treaties. ${ }^{17}$ However, since it is a new tax that is explicitly not imposed on net income, it is hard to see how the treaties apply.

\section{BEPS}

The original BEPS action plan explicitly stated that there would not be a fundamental change to the PE rule. ${ }^{18}$ While Action 7 addresses some situations of avoided PEs, the fundamental PE rules including physical presence remain unchanged.

Action 1 was supposed to address the challenges of the digital economy and in particular consider revising the PE concept. ${ }^{19}$ However, in the end the Final Report only mentions three options (a nexus based approach based on significant economic presence, a withholding tax on digital transactions, and an equalization levy) without recommending any. However, the report leaves the door open to countries that wish to adopt such measures "subject to their treaty obligations."

While option 1 (replacing the PE threshold with significant economic presence) and 2 (a new withholding tax on sale proceeds in lieu of income tax) seem to require modifying the treaties, option 3 (equalization tax) does not seem to require treaty modification since it is a new tax. This is presumably why India adopted it, while Australia chose to adopt a new anti-avoidance regime that is arguably consistent with its treaties (under the OECD view, anti-abuse measures are generally not seen as inconsistent with treaties). ${ }^{20}$ The UK presumably acted before it was known what the scope of BEPS entails.

Overall, while the failure of BEPS to address the shortcomings of the PE standard can be seen as a step backward to the $19^{\text {th }}$ century (when the concept was invented), there

17 Paresh Parekh and Vishal Agarwal, Equalization Levy- A Googly!, 1 Global Taxation 54 (2016); Amar Mehta, “Ëqualization Levy” Proposal in Indian Finance Bill 2016: Is It Legitimate Tax Policy or an Attempt at Treaty Dodging, 22 Asia-Pacific Tax Bulletin 2 (2016); for a defence see Report of the Committee on Taxation of E-Commerce, Proposal for Equalization Levy on Specified Transactions (2016).

18 OECD BEPS Action Plan (2013), 11.

19 The groundwork for addressing the PE was laid in the French Colin and Collin report in January 2013, http://www.economic.gouv. $\mathrm{fr} /$ rapport-sur-la-fiscalite-du-secteur-numerique.

20 https://www.oecd.org/tax/treaties/treaty-abuse-discussiondraft-march-2014.pdf. is enough flexibility for countries to act unilaterally and still be treaty compliant. ${ }^{21}$

\section{Toward Destination-Based Corporate Tax?}

Overall, however, these steps are insufficient to address the broad scope of the BEPS phenomenon. They point in the right direction- a corporate tax based on the location of the customers, who are less mobile than the multinationals. But they are tied to existing PE standard, since both the UK and the Australian proposals require a presence in the country to apply. The equalization tax is not so limited, but since it is a gross-based tax the rate is quite low.

The alternative, as various scholars have suggested, is a Destination-Based Corporate Tax (DBCT). ${ }^{22}$ Under DBCT, multinational enterprises (MNEs) would be treated as unitary businesses and taxed based on where they sell their goods or services, i.e., on a destination basis rather than (as in current corporate taxes) primarily on an origin basis. $^{23}$

In recent years, DBCT has attracted some support by economists, such as Alan Auerbach and Mike Devereux. ${ }^{24}$ While the economists tend to advocate a cash flow DBCT, i.e., a corporate tax that is more consumption than income based because MNEs will be allowed to expense capital outlays, both types of taxes apply to corporate rents in the same way. Moreover, the economists' proposals raise similar issues to older DBCT proposals, e.g., in regard to compatibility with treaties or with WTO rules. One important difference between the Auerbach/Devereux proposal and earlier ones is that under Auerbach/Devereux, the tax is imposed on the full value of imports, like a VAT, with no deduction for cost of goods sold. This feature plus ex-

21 See also the Hungarian advertising tax on media providers (2014) and the Israeli circular on Internet Activities of Foreign Corporations, 22 Int'l Transfer Pricing J. 4 (2015) (foreign corporation selling advertising in Israel may have a PE if the site is aimed at the Israeli market). 22 See Devereux and de la Feria, Designing and Implementing a Destination-Based Corporate Tax, WP 14/07 (May 2014).

23 Avi-Yonah ,Slicing the Shadow: A Proposal for Updating U.S. International Taxation, 56 Tax Notes 1511 (March 15, 1993); Avi-Yonah, Clausing \& Durst, Allocating Business Profits for Tax Purposes: A Proposal to Adopt a Formulary Profit Split, 9 Fla. Tax Rev. 497 (2009).

24 Auerbach, Devereux and Simpson, Taxing Corporate Income, NBER Working Paper 14494 (2008); Devereux and de la Feria, Designing and Implementing a Destination-Based Corporate Tax, WP 14/07 (May 2014). 
pensing make the DBCT more a consumption tax than a destination-based CIT. ${ }^{25}$

These proposals have attracted significant critiques, e.g., from Rosanne Altshuler, Harry Grubert and Susan Morse. ${ }^{26}$ I would like to use this opportunity to restate the case for DBCT and reply to some of the common objections to it.

\subsection{Three Reasons For DBCT}

There are three major reasons to adopt DBCT. The first two apply to all unitary tax proposals: That corporate residence is relatively meaningless so that a method is needed to tax MNEs at source, and that the distinction between subsidiaries and branches is artificial and should be discarded. The third supports DBCT specifically, in that it addresses tax competition in a way that other unitary tax (UT) proposals do not. ${ }^{27}$

\subsubsection{Corporate Residence is Meaningless}

As Dan Shaviro has emphasized, corporate residence is a not very meaningful concept because (a) corporations are not physically present anywhere, (b) corporations are not meaningfully subject to redistribution because the incidence of the corporate tax is not on them, (c) corporations do not vote, and (d) even the location of corporate headquarters, which is a more meaningful concept than place of incorporation, can be moved. ${ }^{28}$ The last point is particularly important in the age of inversions. While the

25 The DBCT has now been proposed by Republicans in the House of Representatives as a method for corporate tax reform. See http://taxfoundation.org/blog/house-gop-s-destination-based-cashflow-tax-explained.

26 Altshuler and Grubert, "Formula Apportionment: Is it Better than the Current System and are there Better Alternatives?", 63 National Tax Journal 1145 (2010); Susan C. Morse, Revisiting Global Formulary Apportionment, 29 Va. Tax Rev. 593 (2010).

27 For a general overview of Unitary Taxation, see http: //www.taxjustice.net/2014/01/14/towards-unitary-taxationtransnational-corporations-sol-picciotto/. Unitary taxation or global formulary apportionment refer to proposals to treat multinational enterprises as a signle unit for tax purposes and allocate their profits by formula. The EU CCCTB proposal is one variant, U.S. state corporate tax laws are another. See Avi-Yonah, A Proposal for Unitary Taxation and Formulary Apportionment (UT+FA) to Tax Multinational Enterprises, in Peter Dietsch and Thomas Rixen (eds.), Global Tax Governance, 289 (2016).

28 Shaviro "The Rising Tax-Electivity of U.S. Corporate Residence," 64 Tax L. Rev. 377 (2011). first wave of inversions could be effectively combated by adopting a managed and controlled definition of corporate residency because the top management would not move to Bermuda, this is less effective now that the UK is an attractive location for headquarters. Thus, it would be preferable to have a way of taxing MNEs that does not depend on the residence of the corporate parent and does not draw an increasingly artificial distinction between US- and foreignbased MNEs, such as UT.

\subsubsection{Subsidiaries are Branches}

In the age of "check the box", the distinction between subsidiaries and branches is meaningless. Most MNEs are directed from one central location as a unitary business, and it does not make sense to tax them based on treating subsidiaries but not branches as separate taxpayers. This undermines the arm's length principle and leads directly to UT.

\subsubsection{Tax Competition}

Once the necessity of UT is accepted, the argument for DBCT is that the consumer base is less subject to tax competition than either the location of property or of payroll. The property factor is in any case problematic because of the need for valuation and because the most important type of property of a modern MNE is IP, which is just as evanescent as the MNE itself. As for payroll, from a unilateral US perspective it makes no sense to adopt a rule that would encourage shifting more jobs overseas.

\subsection{Objections}

The following replies to some common objections to DBCT, as summarized for example by Altshuler and Grubert and Morse. $^{29}$

\subsubsection{Why Not a VAT?}

One common reaction to DBCT proposals is that it makes no sense to have an income tax based on the location of consumption, whereas a consumption tax like the VAT

29 See Altshuler and Grubert, supra; Morse, supra. 
should be destination based. ${ }^{30}$ Admittedly, the DBCT is not a consumption tax (even the Auerbach/Devereux cash flow DBCT allows a deduction for wages, so it is not entirely equivalent to a VAT) but in a unilateral context there are good reasons for it, as explained below. The fact that the tax base to be apportioned based on sales is a net base and not a gross base (wages are deductible and capital expenditures are not in my version) means that it is still a corporate income tax and not a consumption tax. As discussed below, it makes more sense to have a balanced formula in a multilateral setting, but a destination based formula is more likely to win acceptance from the many countries that import more than they export.

\subsubsection{Tax Planning}

Another common objection is that it is very easy to tax plan around a DBCT by having the MNE sell good or services to an independent distributor in a tax haven that will then re-sell at a low profit margin into the US. But most MNEs would be reluctant to give up control over distribution, and if they do not the distributor is not independent and can be looked through. ${ }^{31}$ Moreover, even with a truly independent distributor, look through can be applied if there is no meaningful change in the goods or services being provided. Similar rules already apply under the base company rule in Subpart F, and both the Avi-Yonah, Clausing and Durst legislative language and the market fairness act include language designed to address this issue. ${ }^{32}$ The ultimate destination is determined in most VAT contexts and it can also be determined in a DBCT.

\subsubsection{Treaties/PE}

A third objection is that DBCT violates the tax treaties because it will tax MNEs who sell into the US without a PE. But it is not easy to avoid having a PE, or else e-commerce would have already eliminated source-based corporate tax for sellers into the US. And if there is a PE, the residual force of attraction rule can be used to attribute all sales income to the PE. In addition, the OECD is rethinking the PE concept and various countries have modified it, so that it may be time to substitute a numerical threshold for the current $\mathrm{PE}$, even if this requires a treaty override.

30 Morse, supra.

31 See Avi-Yonah, Clausing and Durst, supra. 32 Ibid.

\subsubsection{WTO}

Another objection is that DBCT violates the WTO rules for export subsidies since direct taxes cannot be border adjusted..$^{33}$ The distinction between direct and indirect taxes under WTO rules is not entirely clear; consumption tax proposals in the US typically argue that they do not violate the rule even if they are not VATs because of the deduction for wages. Nor is it clear why DBCT is objectionable if it applies to all US sales by both domestic and foreign sellers, similarly to a VAT. But assuming DBCT is a WTO violation, it will take many years of litigation to reach the sanctions stage, during which the US can renegotiate the WTO rules or persuade other countries to accept DBCT. No WTO challenge has been launched against US state DBCTs despite calls to do so, and this issue is ultimately a political question.

\subsubsection{Tax Equity}

It has also been argued that DBCT discriminates against developing countries that export more than they import and will therefore lose revenue. This is not true overall, since the BRICS would benefit from DBCT as they are immense markets, and other developing countries are already impacted by tax competition. ${ }^{34}$ In other cases adjustments can be made, but this is hardly an argument against unilateral US adoption of DBCT. If the US were to adopt DBCT, this would put pressure on other countries to do the same, since otherwise multinationals that export could move to the US and pay not tax on exports to other countries. Eventually, this is likely to lead either to agreement on a balanced formula (like the EU's CCCTB proposal) or to world-wide adoprtion of DBCT.

\subsubsection{Double Taxation}

Perhaps the most important debate is about how other countries would adjust to the US adopting DBCT. AviYonah, Clausing and Durst have argued that there would be a lot of pressure on other countries to follow suit be-

33 Avi-Yonah, The WTO, Export Subsidies, and Tax Competition, in Michael Lang, Judith Herdin and Ines Hofbauer (eds.), WTO and Direct Taxation 115 (Linde, 2005).

34 Avi-Yonah and Margalioth, Taxation in Developing Countries: Some Recent Support and Challenges to the Conventional View, 27 Va. Tax Rev. 1 (2007) 
cause otherwise their MNEs would move to the US and export from there. Morse argues that this is not true because they can abolish their corporate tax or at least grant tax holidays. But in that case there would be no double taxation, and the most cogent argument against DBCT is the concern that both origin and destination countries will tax the same income. In my opinion it is always better to put the onus of preventing such double taxation on the MNEs themselves; if they do not like it let them move to the US or lobby the origin country for a tax holiday (which they do anyway, but under current rules that results in double non-taxation of immense amounts of income). If there is to be a single tax on MNEs, from a US perspective it is better that it be a DBCT one than an origin-based one.

\section{Conclusion}

The UK, Australian and Indian attempts to impose tax on foreign corporations deriving extensive revenue from the domestic market without a PE all indicate that in the presence of BEPS, taxation based on the market is a way to ensure the continued robustness of the CIT. While the OECD retreated from its initial commitment to addressing the digital economy, it has left sufficient leeway for countries to move forward unilaterally. If the U.S., for example, were to adopt DBCT, it is likely that other countries would follow, like they did when the US adopted CFC rules. ${ }^{35}$ This may well be the $21^{\text {st }}$ century way to protect the CIT base against BEPS.

\section{References}

Altshuler, Rosanne and Harry Grubert. 2010. "Formula Apportionment: Is it Better than the Current System and are there Better Alternatives," National Tax Journal 63(4) 1145.

Auerbach, Alan and Michael Devereux and Helen Simpson (2008). “Taxing Corporate Income," NBER Working Paper 14494.

Australian Government Treasury. 2015. Tax Laws Amendment (Tax Integrity: GST and Digital Products) Bill 2015 "Exposure Draft Explanatory Material:" 1-23.

Avi-Yonah, Reuven. 2016. "A Proposal for Unitary Taxation and Formulary Apportionment (UT+FA) to Tax Multinational Enterprises," in Peter Dietsch and Thomas Rixen (eds.), Global Tax Governance, 289.

35 For more examples see Avi-Yonah, Constructive Unilateralism: U.S. Leadership and International Taxation, 42 International Tax J. 17 (2016)
Avi-Yonah, Reuven. 2016. "Constructive Unilateralism: U.S. Leadership and International Taxation," 42 International Tax J. 17.

Avi-Yonah, Reuven. 2005. "The WTO, Export Subsidies, and Tax Competition," in Michael Lang, Judith Herdin and Ines Hoffiauer (eds.), WTO and Direct Taxation 115 (Linde, 2005).

Avi-Yonah, Reuven and Nicola Sartori. 2012. "International Taxation and Competitiveness: Foreword," 65 Tax L Rev 313.

Avi-Yonah, Reuven and Yorman Margalioth. 2007. "Taxation in Developing Countries: Some Recent Support and Challenges to the Conventional View," 27 Va. Tax Rev. 1.

Avi-Yonah, Reuven and Yaron Lahav. 2012. "The Effective Tax Rates of the Largest US and EU Multinationals”, $65 \operatorname{Tax} L \operatorname{Rev} 375$.

Baker, Philip. 2015. “Diverted Profits Tax: A Partial Response,” British Tax Review 167.

Butler, Michael and Marianna Danby. 2015. "Draft Legislation Released for Anti-Google Tax," Int'l Transfer Pricing Journal 349 (Nov.).

Cerioni, Luca. 2015. "The New "Google Tax": The "Beginning of the End" for Tax Residence as a Connecting Factor for Tax Jurisdiction?" European Taxation 185 May.

Devereux, Michael and Rita, de la Feria. 2014. "Designing and Implementing a Destination-Based Corporate Tax," WP 14/07 May.

European Commission. 2012. Ruling of 15 March, RG 2017-07.

French Digital Council. 2013. "Report of a Taxation of the Digital Sector." http://www.economic.gouv.fr/rapport-sur-la-fiscalitedu-secteur-numerique

Fone, Douglas. 2015. "The Diverted Profits Tax," 16 Transfer Pricing Int'l J. 24.

HMRC (HM Revenue and Customs). 2015 "Diverted Profits Tax: Interim Guidance." March, 37.

Hungarian Ministry of Finance and Israel Tax Authority. "Hungarian advertising tax on media providers," (2014) and the "Israeli circular on Internet Activities of Foreign Corporations", 22 Int'l Transfer Pricing J. 4 (2015).

Kluwer International Tax Blog. 2015. "Un Model Services Permanent Establishment: What you do-not-where you do it." http:// kluwertaxblog.com/2015/08/12/un-model-services-permanent-e stablishment-what-you-do-not-where-you-do-it/

Mehta, Amar. 2016. "Equalization Levy” Proposal in Indian Finance Bill 2016: Is It Legitimate Tax Policy or an Attempt at Treaty Dodging?", 22 Asia-Pacific Tax Bulletin 2.

Ministry of Finance, Government of India: Report of the Committee on Taxation of E-Commerce. 2016. "Proposal for Equalization Levy on Specified Transactions."

Morse, Susan C. 2010. "Revisiting Global Formulary Apportionment," 29 Va. Tax Rev. 593.

Neidle, Dan. 2015. "The Diverted Profits Tax: Flawed by Design?" British Tax Review 147.

OECD (Organization for Economic Co-operation and Development). 2014. "BEPS Action 6: Preventing the Granting of Treaty Benefits in Inappropriate Circumstances."

OECD (Organization for Economic Co-operation and Development). 2016. “Tax on corporate profits." (indicator) https://data.oecd.org /tax/tax-on-corporate-profits.htm\#indicator-chart, https://www. oecd.org/tax/treaties/treaty-abuse-discussion-draft-march-2014 .pdf

Parekh, Paresh and Vishal Agarwal. 2016. "Equalization Levy- A Googly!”, 1 Global Taxation 54.

Peacock, Jonathan. 2015. “U.K.'s Diverted Profits Tax: A Regime Much, 50 Much Broader Than its True Target?” 17 European Tax Ser- 
vice 4.

Picciotto, Sol. 2015. “The U.K.'s Diverted Profits Tax: An Admission of Defeat or a Pre-Emptive Strike?” Tax Notes International 239 (January 19).

Richardson, David. 2015. “Corporate Tax Avoidance," The Australia Institute, Submission 62 (Feb.) 1-16.

Rutherford, Paul. 2015. “The U.K.'s Google Tax-First Thoughts,” 42 Tax Planning International Review 4.

Schmidt, Peter K. 2016. "Taxation of Controlled Foreign Companies in Context of the OECD/G20 Project on Base Erosion and Profit Shifting as well as the EU Proposal for the Anti- Tax Avoidance Directive - An Interim Nordic Assessment." Nordic Tax J.
Self, Heather. 2015. "The UK's New Diverted Profit Tax: Compliance with EU Law," 43 Intertax 333.

Shaviro, Daniel. 2011. "The Rising Tax-Electivity of U.S. Corporate Residence", 64 Tax L. Rev. 377.

Tax Justice Network. 2014. "Towards Unitary Taxation of Transnational Corporations," http://www.taxjustice.net/2014/01/14/tow ards-unitary-taxation-transnational-corporations-sol-picciotto/

U.S. Department of the Treasury. 2016. "Tax Expenditures." https: //www.treasury.gov/resource-center/tax-policy/Documents/TaxExpenditures-FY2016.pdf 